\title{
Obliczenia złączy spawanych poddanych obciążeniom statycznym i zmęczeniowym według Eurokodu 3
}

\author{
Calculation of static and fatigue load capacity \\ of welds in Eurocode 3
}

\section{Streszczenie}

W części 1-8 Eurokodu 3 (rozdział 4) podano zasady oceny nośności spoin obciążonych statycznie, a w części 1-9 Eurokodu 3 obliczanie spoin narażonych na obciążenia zmęczeniowe. Zasady oceny nośności spoin podane w tych normach różnią się często w przyjętych modelach obliczeniowych i szczegółowych propozycjach dotyczących projektowania węzłów w porównaniu z wymaganiami normy polskiej PN-90/B-03200. Celem artykułu jest wykazanie tych różnic i omówienie merytorycznych podstaw przyjętych modeli obliczeniowych oceny nośności spoin.

\section{Abstract}

The method of calculation of static load capacity of weld is presented in the part 1-8 of Eurocode 3 (chapter 4 ) and the calculation of weld with fatigue load is presented in the part 1-9 of Eurocode 3. The rules of calculation of weld load capacity presented in those codes are shown differences in the calculation models and also in proposals of nodes design in comparison to the polish standard $\mathrm{PN}-90 / \mathrm{B}-03200$. Differences in codes and the standard are presented in this article. Moreover, the basis of calculation models of weld load capacity are discussed.

\section{Wstęp}

Złącza wykonywane metodami spawalniczymi uważano powszechnie za najsłabsze miejsca w konstrukcjach stalowych $[1 \div 3]$. Przyjmowano, że mają one nie tylko obniżoną, w stosunku do materiału rodzimego, wytrzymałość statyczną i dynamiczną (udarową i zmęczeniową) oraz odporność na korozję, lecz również, że wykazują skłonność do pęknięć eksploatacyjnych $[4,5]$. W ostatnich 20 latach dokonał się jednak ogromny postęp w zakresie materiałów i technik spawalniczych, który istotnie wpłynął na właściwości złączy. Ulepszono znacząco klasyczne techniki, opracowano metody hybrydowe, wdrożono komputerowe metody sterowania [6]. Osiągnięty został poziom technologiczny, przy którym złącze nie powinno być słabsze - w szerokim pojęciu - od materiału rodzimego. Powyższe stwierdzenie znalazło zastosowanie

Dr hab. inż. Bernard Wichtowski, prof. ZUT - Zachodniopomorski Uniwersytet Technologiczny, Szczecin. w projektowaniu oraz obliczaniu połączeń i węzłów spawanych projektowanych w konstrukcjach stalowych według wymagań Eurokodu 3 [7, 8].

W najbliższym czasie będą obowiązywać w Polsce tylko przepisy europejskie, zatem pojawia się potrzeba zaznajomienia z nimi kadry technicznej. Takiemu celowi ma służyć niniejszy artykuł, w którym przedstawiono metodykę obliczania spoin czołowych i pachwinowych obciążonych statycznie oraz znajdujących się pod obciążeniem, które powoduje powtarzające się zmiany naprężeń. Obliczenia wytrzymałościowe omówiono zgodnie z wymaganiami nowych norm europejskich.

\section{Założenia obliczeniowe}

Obliczane według normy PN-EN 1993-1-8 [7] połączenia spawane powinny spełniać następujące postanowienia ogólne:

- łączona stal konstrukcyjna o właściwościach wg normy [8] ma granice plastyczności $f_{y}$ nieprzekraczającą $460 \mathrm{~N} / \mathrm{mm}^{2}$ i grubość nie mniejszą niż 
4 mm; w przypadku połączeń spawanych wyrobów cieńszych stosuje się PN-EN 1993-3 [9];

- stopiwo musi mieć nominalne wartości granicy plastyczności, wytrzymałości na rozciąganie, wydłużenia przy zerwaniu i minimalnej pracy łamania Charpy'ego $\mathrm{V}$ co najmniej takie same jak materiał rodzimy;

- dla spoin obciążonych statycznie wymagany jest poziom jakości C wg PN-EN ISO 5817 [10].

Obliczanie połączeń, w których występuje kilka części i odcinków spoin, wymaga określenia podziału na poszczególne odcinki spoin. Podział obciążenia w połączeniu może być określony w dowolny sposób, za pomocą analizy sprężystej lub plastycznej, przy spełnieniu poniższych wymagań:

- siły i momenty wewnętrzne przyjmowane w analizie są w równowadze z siłami i momentami przyłożonymi do węzła,

- nośność każdego elementu w węźle jest wystarczająca do przeniesienia wewnętrznych sił i momentów,

- przyjęty rozkład sił wewnętrznych odpowiada sztywnościom względnym elementów węzła,

- deformacje odpowiadające przyjętym siłom w węźle nie przekraczają zdolności do odkształceń łączników spoin i łączonych części, a deformacje w modelu obliczeniowym wynikają z możliwych obrotów lub przemieszczeń ciała sztywnego.

Zasady obliczania połączeń spawanych przedstawione w normie PN-EN 1993-1-8 [7] są bardziej ogólne, niż w normie PN-90/B03200 [2], gdzie w większym stopniu podano gotowe schematy obliczeniowe i wzory dotyczące różnych typów połączeń spawanych.

\section{Nośność obliczeniowa spoin pachwinowych}

Efektywną długość spoiny pachwinowej $I_{w}$ przyjmuje się jako długość, na której spoina ma pełny przekrój. Jest to długość całkowita spoiny zmniejszona o dwie grubości spoiny, $a_{w}$. Jeśli spoina ma pełny przekrój na całej długości, łącznie z początkiem i końcem, redukcja długości efektywnej nie jest wymagana. W obliczeniu uwzględnia się tylko spoiny o długości: $I_{i} \geq 30 \mathrm{~mm}$ oraz $l_{i} \geq 6 a_{w}$, a obliczeniowe pole przekroju spoin przyjmuje się $A_{w}=\Sigma a_{w} I_{w}$.

Jako efektywną grubość spoiny pachwinowej $a_{w}$ przyjmuje się wysokość największego trójkąta wpisanego w obrys przekroju poprzecznego spoiny, mierzoną prostopadle do zewnętrznego boku tego trójkąta (rys. 1). Zaleca się projektować spoiny tak, aby ich grubość nie była mniejsza niż $3 \mathrm{~mm}$. Przy określaniu nośności obliczeniowej spoiny pachwinowej z głębokim przetopem można uwzględnić dodatkową grubość spoiny, o ile głębokość wtopienia potwierdzą badania technologiczne. Norma [2] dla tego typu spoin zalecała przyjmować zwiększoną grubość obli-
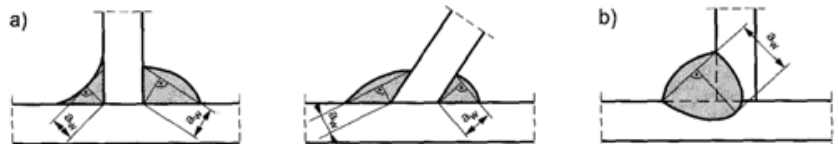

Rys. 1. Grubość spoin pachwinowych: a) o różnym kącie pochylenia ścianek, b) z głębokim przetopem

Fig. 1. Throat of fillet weld: a) with different angle, b) with weld deep penetration

czeniową: $a=1,3 a_{w}$ - dla spoin jednowarstwowych, $a=1,2 a_{w} \leq a_{w}+2 \mathrm{~mm}-$ dla spoin wielowarstwowych.

Spoiny pachwinowe mogą być stosowane do łączenia części, których ścianki tworzą kąt od $60^{\circ}$ do $120^{\circ}$. W przypadku kąta mniejszego niż $60^{\circ}$ spoinę należy traktować jako czołową z niepełnym przetopem.

Dla długich spoin w połączeniach zakładkowych, dłuższych niż $150 a_{w}$, norma [7] zaleca zmniejszenie ich nośności współczynnikiem redukcyjnym:

$$
\beta_{L w, 1}=1,2-\frac{0,2 l_{w}}{150 a_{w}} \leq 1,0
$$

Natomiast w przypadku spoin o $I_{w}>1,7 \mathrm{~m}$, łączących żebra w elementach blachownicowych, przyjmuje się współczynnik redukcyjny w postaci:

$$
\beta_{L w, 2}=1,1-\frac{l_{w}}{17} \leq 1,0 \text { oraz } \geq 0,6
$$

gdzie: $I_{w}$-długość spoiny, m.

Nośność obliczeniową spoin pachwinowych sprawdza się za pomocą dwóch metod: metodą kierunkową (wektorową) lub metodą uproszczoną.

Metoda kierunkowa jest metodą ogólną, wiernie oddającą zachowanie się spoin pachwinowych pod wpływem obciążenia. Przyjmuje się równomierny rozkład naprężeń w przekroju spoiny, a jej nośność obliczeniową określa się z zależności:

$$
\sqrt{\sigma_{\perp}^{2}+3\left(\tau_{\perp}^{2}+\tau_{\mathrm{II}}^{2}\right)} \leq \frac{f_{u}}{\beta_{w} \gamma_{M 2}} \text { oraz } \sigma_{\perp} \leq 0,9 \frac{f_{u}}{\gamma_{M 2}}
$$

gdzie: $\sigma_{\perp}, \tau_{\perp}, \tau_{\|}$- składowe stanu naprężeń w przekroju spoiny, odpowiednio normalne i styczne do płaszczyzny jej przekroju (rys. 2); $f_{u}$ - nominalna wytrzymałość na rozciąganie materiału słabszej z łączonych części, $360 \div 560 \mathrm{~N} / \mathrm{mm}^{2}$ dla $t \leq 40 \mathrm{~mm}$ i $340 \div 550 \mathrm{~N} / \mathrm{mm}^{2}$ dla $40<t \leq 80 \mathrm{~mm}$ w zależności od gatunku stali [8]; $\beta_{w}=0,8 \div 1,0$ - współczynnik korelacji uwzględniający wyższe właściwości mechaniczne materiału spoiny w stosunku do materiału spawanego [7]; $V_{M 2}=1,25$ - współczynnik bezpieczeństwa przy sprawdzaniu nośności na rozerwanie [8].
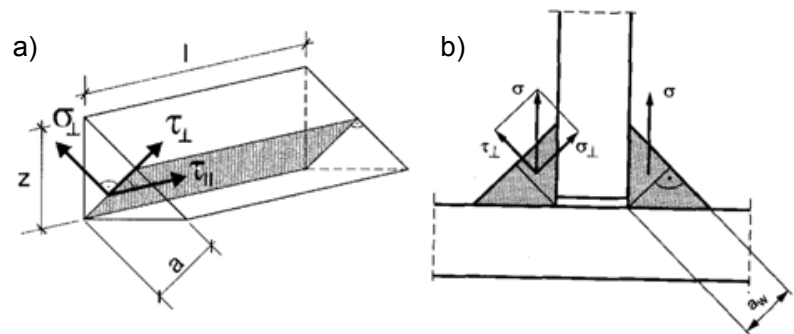

Rys. 2. Składowe naprężeń w przekroju spoiny pachwinowej: a) widok podłużny, b) przekrój poprzeczny

Fig. 2. Components of stress in the section of fillet weld: a) the weld longitudinal section, b) the weld cross-section 

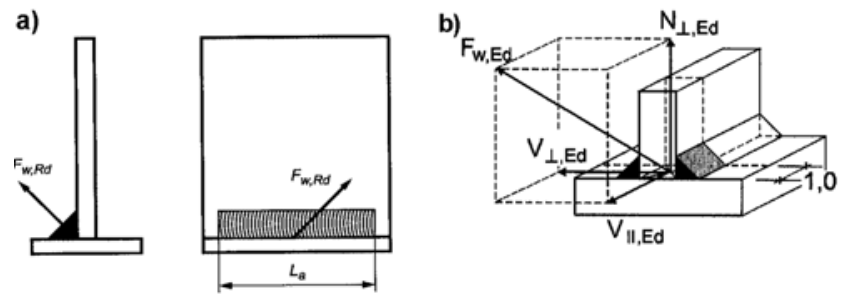

Rys. 3. Wyznaczanie: a) nośności spoiny pachwinowej, b) wypadkowej siły obciążenia spoiny [11]

Fig. 3. The evaluation of: a) the fillet weld load capacity, b) the resultant force of the weld load [11]

We wzorze (3) obliczeniowa nośność spoiny jest związana z granicą wytrzymałości materiału $f_{u^{\prime}}$ a nie jego granicą plastyczności $f_{y^{\prime}}$ niemniej jednak wzór (3) jest porównywalny ze wzorem na wytrzymałość spoin pachwinowych w złożonym stanie naprężenia według normy [2], w którym bazowano na $f_{y}$.

Dla spoin o przekroju równoramiennego trójkąta prostokątnego: $\sigma_{\perp}=\tau_{\perp}=\sigma / \sqrt{2}$ (rys. 2b), a drugi warunek we wzorze (3) jest zawsze spełniony i nie wymaga sprawdzenia.

Drugą metodą obliczania nośności spoin pachwinowych, wg normy [7], jest metoda uproszczona. Niezależnie od położenia płaszczyzny przekroju spoiny względem działającej siły, nośność obliczeniowa na jednostkę długości $F_{w, R d}$ określona jest wzorem:

$$
F_{w, R d}=f_{v w, d} a_{w}
$$

gdzie: $f_{w w, d}$ - obliczeniowa wytrzymałość spoiny na ścinanie

$$
f_{v w, d}=\frac{f_{u} / \sqrt{3}}{\beta_{w} \gamma_{M 2}}
$$

Warunek (4) jest spełniony, gdy w każdym punkcie spoiny wypadkowa wszystkich przenoszonych sił przez jednostkę jej długości spełnia warunek:

$$
F_{w, E d} \leq F_{w, R d}
$$

gdzie: $F_{w, E d}$ - wartość obliczeniowa siły działającej na jednostkę długości spoiny (rys. 3).

Zapis (6) jest warunkiem wytrzymałości, w którym wypadkowa naprężeń $w$ każdym punkcie spoiny jest nie większa od obliczeniowej wytrzymałości spoiny na ścinanie wg (5).

\section{Nośność obliczeniowa spoin czołowych}

Grubość obliczeniową $a_{w}$ spoin czołowych przyjmuje się równą grubości cieńszej z łączonych części, a przy łączeniu elementów o jednakowej grubości równą tej grubości. Grubość spoin czołowych z niepełnym przetopem przyjmuje się równą głębokości rowka do spawania (rys. 4a). W przypadku wykonywania tych spoin z głębokim przetopem przyjmuje się ich grubość
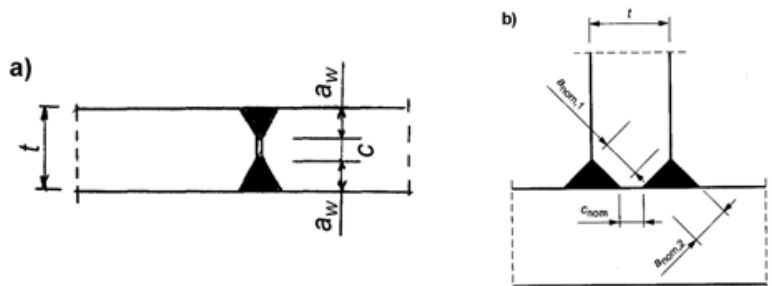

Rys. 4. Złącza z niepełnymi spoinami: a) złącze doczołowe, b) połączenie teowe

Fig. 4. Incomplete penetration of joints: a) butt weld, b) tee joint

nie większą od głębokości przetopu regularnie uzyskiwanej i wykazanej wstępnymi badaniami. Połączenie teowe $z$ dwiema spoinami czołowo-pachwinowymi (rys. 4b), gdy spełnione są warunki: $a_{\text {nom } 1}+a_{\text {nom } 2} \geq t$ oraz $c_{\text {nom }} \leq t / 5$ i $c_{\text {nоm }} \leq 3 \mathrm{~mm}$, można traktować jako połączenie spoiną czołową o grubości $a_{w}=t$.

\section{$Z$ pełnym przetopem}

Nośność obliczeniowa spoin czołowych z pełnym przetopem jest nie mniejsza od nośności słabszej z łączonych części, przy czym materiał spoiny musi mieć właściwości mechaniczne $\left(f_{y}, f_{u}\right)$ nie mniejsze niż materiał rodzimy [7].

Nośność obliczeniową tych spoin, dla różnych stanów granicznych nośności, określa się wg [8]. W każdym przekroju odpowiednie warunki nośności określane są dla obliczeniowych efektów oddziaływań - pojedynczych lub złożonych przy: rozciąganiu, ściskaniu, zginaniu, ścinaniu, skręcaniu, zginaniu ze ścinaniem, zginaniu z siłą podłużną oraz zginaniu ze ścinaniem i siłą podłużną. Dla tych stanów granicznych nośności, formułę nośności obliczeniowej przyjmuje się stosownie do klasy przekroju, określonej według granicznych proporcji części ściskanych z [8].

Przykładowo nośność przekrojów przy: rozciąganiu, zginaniu i ścinaniu określa się według niżej podanych zasad.

a) Warunek nośności rozciąganego styku spawanego siłą podłużną $N_{E d}$, niezależnie od klasy przekroju ma postać:

$$
\frac{N_{E d}}{N_{t, R d}} \leq 1,0 \text { gdzie } N_{t, R d}=\frac{A_{w} f_{y}}{\gamma_{M 0}}
$$

b) Warunek nośności spoiny czołowej przy jednokierunkowym zginaniu momentem $M_{E d}$ ma postać:

$$
\frac{M_{E d}}{M_{c, R d}} \leq 1,0
$$

gdzie $M_{c, R d}-$ obliczeniowa nośność przekroju w zależności od jego klasy:

$M_{c, R d}=\frac{W_{p l} f_{y}}{\gamma_{M 0}}(\mathrm{kl} .1 \mathrm{i} 2)=\frac{W_{e l, \min } f_{y}}{\gamma_{M 0}}(\mathrm{kl} .3)=\frac{W_{e f f, \min } f_{y}}{\gamma_{M 0}}(\mathrm{kl} .4)(9)$

gdzie: $W_{p l}$ - wskaźnik oporu plastycznego, $W_{e l, \text { min }}-$ najmniejszy sprężysty wskaźnik wytrzymałości, $W_{\text {eff, min }}$ - najmniejszy wskaźnik wytrzymałości przekroju współpracującego. 
c) Warunek nośności przekroju przy ścinaniu obliczeniową siłą poprzeczną $V_{E d}$ ma postać:

$$
\frac{V_{E d}}{V_{c, R d}} \leq 1,0
$$

gdzie: $V_{c, R d}-$ obliczeniowa nośność przekroju przy ścinaniu,

- przy projektowaniu plastycznym

$$
V_{p l, R d}=\frac{A_{v}\left(f_{y} / \sqrt{3}\right)}{\gamma_{M 0}}
$$

gdzie: $A_{v}$ - pole przekroju czynnego przy ścinaniu; w zależności od przekroju poprzecznego (kształtowniki i spawane przekroje skrzynkowe oraz rury prostokątne) przyjmowane wg p. 6.2.6(3) normy [8],

- przy ścinaniu sprężystym

$$
\frac{\tau_{E d}}{f_{y} /\left(\sqrt{3} \gamma_{M 0}\right)} \leq 1,0 \text { przy czym } \tau_{E d}=\frac{V_{E d} S}{J t}
$$

gdzie: $S$ - moment statyczny względem osi głównej przekroju części przekroju pomiędzy punktem, w którym oblicza się $\tau_{E d^{\prime}}$ a brzegiem przekroju, $J$ - moment bezwładności, $t$ - grubość w rozpatrywanym punkcie,

- w przypadku przekrojów dwuteowych, gdy $A_{f} / A_{w} \geq 0,6$, naprężenia ściskające w środniku można obliczać według wzoru:

$$
\tau_{E d}=\frac{V_{E d}}{A_{w}}
$$

gdzie: $A_{f}$ - pole przekroju pasa, $A_{w}$ - pole przekroju środnika: $A_{w}=h_{w} t_{w}$

\section{Z niepełnym przetopem}

Nośność obliczeniową spoin czołowych z niepełnym przetopem wyznacza się, stosując metodę dla spoin pachwinowych z głębokim przetopem. Grubość tych spoin przyjmuje się nie większą od głębokości przetopu regularnie uzyskiwanej i wykazanej w badaniach wstępnych. Praktycznie, grubość efektywną tych spoin przyjmuje się równą głębokości rowka ukosowania $[11 \div 13]$.

\section{Wytrzymałość zmęczeniowa spoin}

W grupie stalowych eurokodów konstrukcyjnych obejmujących PN-EN 1993, przy projektowaniu konstrukcji narażonych na obciążenia zmęczeniowe, na uwagę zasługują dwie części podstawowe PN-EN 1993-1-9 [14] i PN-EN 1993-1-10 [15].

W Eurokodzie 1993-1-9 podano metody oceny nośności zmęczeniowej elementów połączeń i węzłów narażonych na obciążenia powodujące zmęczenie. W Eurokodzie 1993-1-10 podano wytyczne doboru stali na konstrukcje ze względu na odporność na kruche pękanie i na ciągliwość międzywarstwową elementów spawanych, w których może wystąpić znaczne rozwarstwienie jako skutek procesów wytwarzania. Wytyczne doboru stali ze względu na jej odporność na kruche pękanie stosuje się w odniesieniu do nowych konstrukcji, gdyż nie dotyczą one konstrukcji użytkowanych. Wymagania odnoszą się do elementów rozciąganych i elementów zginanych, narażonych na zmęczenie, przy czym właściwości materiałów przyjmuje się w odniesieniu do grup jakościowych stali w normach wyrobu [16].

Wytrzymałość zmęczeniowa do celów normatywnych jest określona za pomocą krzywych [14]:

- dla nominalnych naprężeń normalnych:

$$
\log N=\log a-m \log \Delta \sigma_{R}
$$

- dla nominalnych naprężeń stycznych:

$$
\log N=\log a-m \log \Delta \tau_{R}
$$

gdzie: $\Delta \sigma_{R}-$ wytrzymałość zmęczeniowa (przy naprężeniach normalnych); $\Delta \tau_{R}$ - wytrzymałość zmęczeniowa przy ścinaniu; $N$ - liczba cykli naprężeń; $m$ - stała nachylenia krzywych zmęczeniowych: $m=3$ lub $m=5$; log a - stała, związana z $m$ i kategorią karbu.

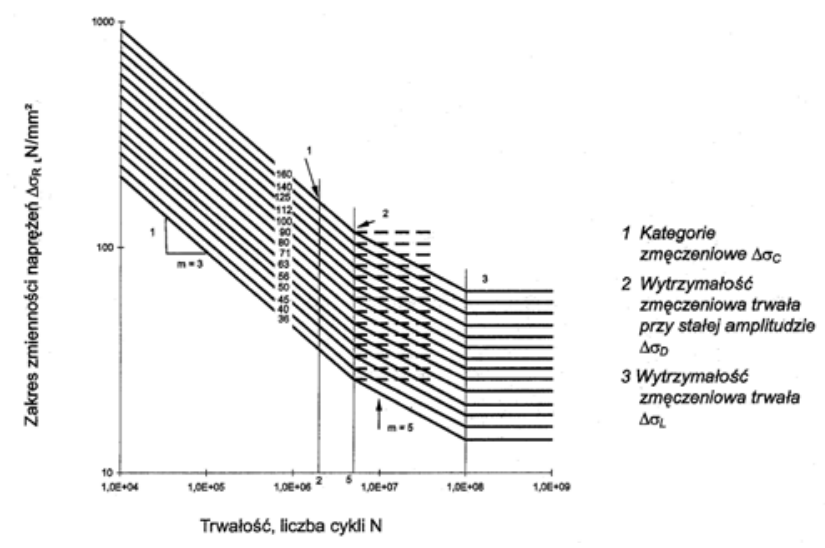

Rys. 5. Krzywe wytrzymałości zmęczeniowej dla zakresów naprężeń normalnych

Fig. 5. Fatigue strength lines for normal stress

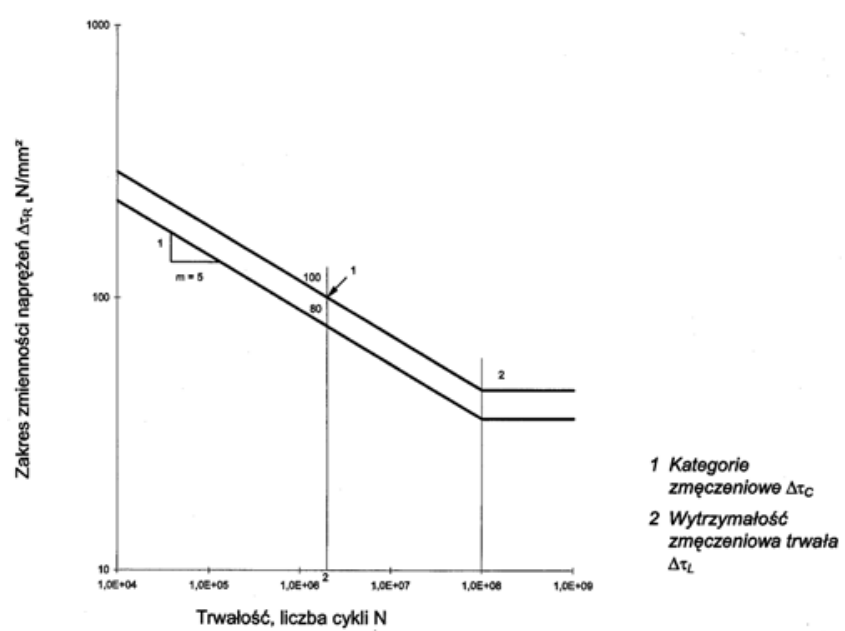

Rys. 6. Krzywe wytrzymałości zmęczeniowej dla zakresów naprężeń stycznych

Fig. 6. Fatigue strength lines for shearing stress 
Każda kategoria jest oznaczona za pomoca liczby mianowanej w MPa, która reprezentuje wartości odniesienia $\Delta \sigma_{c}$ lub $\Delta \tau_{c}$, czyli wytrzymałość zmęczeniową przy 2 mln cykli [17]. Krzywe odnoszące się do naprężeń normalnych i stycznych przedstawiono na rysunkach 5 i 6 .

Odpowiednią kategorię karbu przypisuje się konkretnemu szczegółowi konstrukcyjnemu, a wartość zakresów zmienności naprężeń $\Delta \sigma_{C}$ dla liczby cykli $N=2 \times 10^{6}$ ustalono dla $75 \%$ przedziału ufności z 95\% prawdopodobieństwem przeżycia, z uwzględnieniem odchylenia standardowego i liczebności próby $(\geq 10)$.

Kategorie zmęczeniowe $\Delta \sigma_{C}$ i $\Delta \tau_{C}$, odpowiadające naprężeniom nominalnym, podano w normie [14], gdzie oprócz detali konstrukcyjnych i przypisanych im kategorii karbu podano również opis otworów, śrub, spoin, technologii spawania oraz dodatkowych wymagań konstrukcyjnych i wykonawczych.

Wyniki badań eksperymentalnych niektórych elementów odbiegały od krzywych zmęczeniowych z rysunku 5. Ze względów bezpieczeństwa przypisano im kategorię zmęczeniową o jeden stopień niższą, niż to wynikało z hipotetycznej kategorii zmęczeniowej przy liczbie $N=2 \times 10^{6}$. Te karby w tablicach $8.1 \div 8.10 \mathrm{w}$ normie [14] opatrzono gwiazdką. Ich kategorię zmęczeniową można podwyższyć, pod warunkiem, że zastosuje się zmodyfikowane krzywe wytrzymałości zmęczeniowej wg rysunku $7\left(\Delta \sigma_{D}\right.$ dla $N=2 \times 10^{7}$ cykli oraz $\left.m=3\right)$.

W praktyce projektowej zdarzają się rozwiązania konstrukcyjne, dla których karby nie zostały wymienione $w$ tablicach $8.1 \div 8.10$ normy [14]. Wówczas ocena zmęczenia nie odbywa się przy stosowaniu procedur opartych na zmienności naprężeń nominalnych, lecz na zmienności naprężeń geometrycznych. Naprężeniem geometrycznym jest największe naprężenie główne w materiale rodzimym w pobliżu początku spoiny, uwzględniające wpływ koncentracji naprężeń, spowodowany ogólną geometrią karbu konstrukcyjnego.

W metodzie naprężeń geometrycznych stosuje się kategorie zmęczeniowe podane w Załączniku B normy [14], miarodajne ze względu na inicjację pęknięć:

- przy brzegu spoin czołowych,

- przy brzegu spoin pachwinowych mocujących elementy przyłączane,

- przy brzegu spoin pachwinowych w złączach krzyżowych.

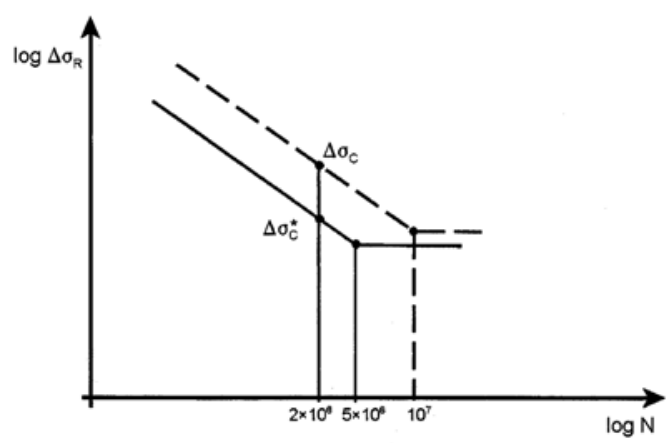

Rys. 7. Alternatywna wytrzymałość $\Delta \sigma_{C}$ dla przypadków $\Delta \sigma_{C}{ }^{*}$ Fig. 7. Alternative strength value $\Delta \sigma_{C}$ for $\Delta \sigma_{C}{ }^{*}$
Dla poprzecznych spoin czołowych o grubości $t>25 \mathrm{~mm}$ oraz dla śrub o średnicach $>30 \mathrm{~mm}$, norma [14] zaleca uwzględniać efekt skali za pomocą współczynników $k_{s}$ podanych $w$ tablicach 8.1 i 8.3. Zredukowana wytrzymałość zmęczeniowa dla tych elementów określana jest wzorem:

$$
\Delta \sigma_{C, \text { red }}=k_{s} \Delta \sigma_{C}
$$

\section{Ocena zmęczenia}

Ocenę zmęczenia przeprowadza się wg normy [14] w odniesieniu do wszystkich krytycznych miejsc (szczegółów) konstrukcji, stosując: metodę tolerowanych uszkodzeń lub metodę bezwarunkowej trwałości.

Metoda tolerowanych uszkodzeń zapewnia odpowiednią niezawodność konstrukcji pod warunkiem, że w okresie eksploatacji konstrukcja jest poddawana kontroli i zabiegom utrzymania, mającym na celu wykrycie i usunięcie uszkodzeń zmęczeniowych. Metodę tę można stosować, jeśli w wypadku uszkodzenia zmęczeniowego możliwa jest redystrybucja sił między elementami konstrukcji.

Metoda bezwarunkowej trwałości zapewnia odpowiednia niezawodność konstrukcji bez konieczności regularnych kontroli na obecność uszkodzeń zmęczeniowych w okresie eksploatacji. Metodę tę stosuje się, gdy lokalne pęknięcia w jakiejś części mogłyby doprowadzić do zniszczenia elementu lub konstrukcji.

Do oceny zmęczenia w elementach konstrukcji wartości sił wewnętrznych, a następnie naprężeń wyznacza się na podstawie sprężystej analizy konstrukcji pod obciążeniami powodującymi zmęczenie. Naprężenia oblicza się jak w przypadku stanu granicznego użytkowalności. Miarodajnymi naprężeniami w materiale rodzimym są: nominalne naprężenia normalne $\sigma$ i nominalne naprężenia ścinające $\tau$.

Naprężenia wyznacza się według klasycznej wytrzymałości materiałów, jak dla pręta o przekroju pryzmatycznym:

$$
\begin{gathered}
\sigma=\frac{N}{A}+\frac{M_{y} z}{J_{y}}+\frac{M_{z} y}{J_{z}} \\
\tau=\frac{V S}{J t}
\end{gathered}
$$

gdzie: $N, M_{y}, M_{z}$ - odpowiednio siła podłużna i momenty zginające; $A, J_{y}, J_{z}$ - pole i momenty bezwładności przekroju poprzecznego pręta; $z, y$ - rzędne rozpatrywanego punktu, w którym są obliczane naprężenia, $V$ - siła poprzeczna w płaszczyźnie ścinania; $S, J, t$-zgodnie $z$ wzorem (12).

W połączeniach nośnych na spoiny czołowe z ich niepełnym przetopem, lub na spoiny pachwinowe, siły przenoszone przez spoiny o jednostkowej długości rozkłada się na składowe: poprzeczną i równoległą do podłużnej osi spoiny (rys. 8). W spoinach tych ustala się naprężenia: normalne $\sigma_{w f}$, poprzeczne względem 


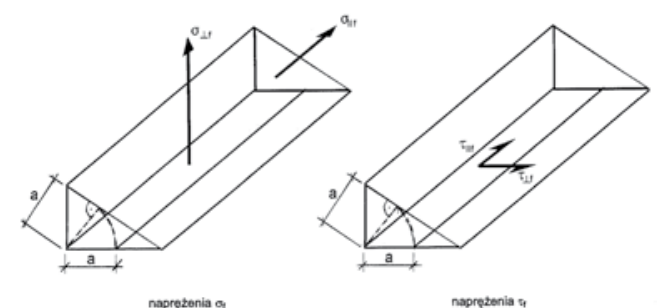

Rys. 8. Składowe naprężeń w spoinach pachwinowych

Fig. 8. Components of stress in fillet weld

osi spoiny: $\sigma_{w f}={\sqrt{\sigma_{\perp}{ }^{2}+\tau_{\perp}}}^{2}$, oraz ścinające $\tau_{w f}$ wzdłuż osi spoiny: $\tau_{w f}=\tau_{\| f}$, i dla nich przeprowadza się dwa odrębne sprawdzenia. Takie postępowanie różni się od tego, które stosuje się przy sprawdzaniu nośności spoin w metodzie kierunkowej wg (3).

W ocenie zmęczenia, nominalne, zmodyfikowane lub geometryczne zakresy zmienności naprężeń nie powinny przekraczać wartości:

$\Delta \sigma \leq 1,5 f_{y}-$ w przypadku naprężeń normalnych

$\Delta \tau \leq 1,5 f_{y} / \sqrt{3}-$ w przypadku naprężeń ścinających

Spełnienie warunków (18) zapewnia, że konstrukcja nie ulegnie zmęczeniu w zakresie niskocyklowym (przy liczbie cykli mniejszej niż 104) [18].

Zmęczenie wywołują zmieniające się naprężenia. Przebieg zmienności naprężeń w czasie nazywany jest widmem lub spektrum naprężeń (rys. 9). Widmo o stałej amplitudzie charakteryzuje się wartościami naprężeń maksymalnych $\sigma_{\max }$ i minimalnych $\sigma_{\min }$ w poszczególnych cyklach oraz naprężeniami średnimi $\sigma_{m}=0,5\left(\sigma_{\max }+\sigma_{\min }\right)$.

Zakres zmienności naprężeń normalnych (stycznych) przyjmuje się, w rozpatrywanym punkcie konstrukcji, jako:

$$
\begin{aligned}
& \Delta \sigma=\sigma_{\max }-\sigma_{\min } \\
& \left(\Delta \tau=\tau_{\max }-\tau_{\min }\right)
\end{aligned}
$$

a)

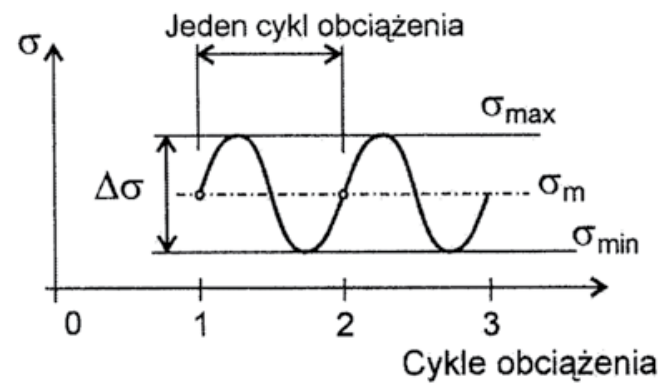

b)

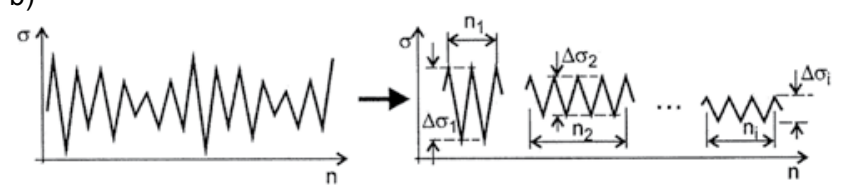

Rys. 9. Widma naprężeń: a) o stałej amplitudzie, b) niejednorodne

Fig. 9. Spectra stress: a) constant amplitude, b) heterogeneous
W przypadku elementów niespawanych lub spawanych odprężonych oraz cykli naprężeń całkowicie lub częściowo ściskających, norma [14] zezwala na przyjmowanie zredukowanego zakresu zmienności naprężeń normalnych, uwzględniając 100\% naprężeń rozciągających $\left(\sigma_{t}\right)$ i $60 \%$ zakresu zmienności naprężeń ściskających $\left(\sigma_{c}\right)$ :

$$
\Delta \sigma=\left|\sigma_{t}\right|+0,6\left|\sigma_{c}\right|
$$

Typowe sekwencje obciążeń, które odwzorowują wiarygodne górne ograniczenie wszystkich zdarzeń obciążeń użytkowych w projektowanym okresie eksploatacji, norma [14] zaleca wyznaczać na podstawie wartości z istniejących podobnych konstrukcji [19]. Typowe cykle obciążenia, występujące $n$ razy w projektowanym okresie użytkowania, podano w załączniku $A$ do normy [14].

Zmiany naprężeń w ciągu całego okresu trwałości konstrukcji pod obciążeniami powodującymi zmęczenie, tworzą historię naprężeń. Do celów globalnej oceny bezpieczeństwa historię tę redukuje się do widma zakresów zmienności naprężeń, czyli do histogramu występowania wszystkich różnych co do wielkości zakresów, zarejestrowanego lub obliczonego dla określonego zdarzenia obciążeniowego. Z nieregularnego, ogólnie biorąc, wykresu naprężeń $\sigma_{i}\left(\tau_{i}\right)-n_{i}$ (rys. 9b) wybiera się odcinek charakterystyczny dla całego widma (załącznik A do normy [14]).

Dla tego odcinka sumuje się liczbę cykli $n_{\max }$ odpowiadającą równoważnemu zakresowi zmienności naprężeń $\Delta \sigma_{i}$. Zliczania cykli w celu zamiany takiego widma na równoważny mu zbiór widm jednorodnych dokonuje się metodą deszczową lub zbiornikową [3, 13, 20, 21].

Sprawdzanie nośności ze względu na zmęczenie polega na wykazaniu, że przy obciążeniach zmęczeniowych spełnione są następujące warunki nośności:

$$
\frac{\gamma_{F f} \Delta \sigma_{E, 2}}{\Delta \sigma_{C} / \gamma_{M f}} \leq 1,0
$$

oraz

$$
\frac{\gamma_{F f} \Delta \tau_{E, 2}}{\Delta \tau_{\mathrm{C}} / \gamma_{M f}} \leq 1, a
$$

W niektórych przypadkach, określonych w tablicach

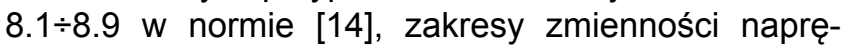
żeń wyznacza się na podstawie naprężeń głównych. W przypadku naprężeń złożonych (jeśli w normie [14] nie podano inaczej) należy wykazać, że spełniony jest warunek:

$$
\left(\frac{\gamma_{F f} \Delta \sigma_{E, 2}}{\Delta \sigma_{C} / \gamma_{M f}}\right)^{3}+\left(\frac{\gamma_{F f} \Delta \tau_{E, 2}}{\Delta \tau_{C} / \gamma_{M f}}\right)^{5} \leq 1,0
$$

gdzie: $\Delta \sigma_{C}$ i $\Delta \tau_{C}$ - wytrzymałość normatywna dla liczby $2 \times 10^{6}$ cykli; $V_{F f}$ - współczynnik częściowy dla równoważnych zakresów zmienności naprężeń o stałej amplitudzie $\left(\gamma_{\mathrm{F} f}=1,0\right) ; \gamma_{\mathrm{Mf}}$ - częściowy współczynnik wytrzymałości zmęczeniowej $\Delta \sigma_{C}$ i $\Delta \tau_{C}-z$ tablicy 3.1 normy [14]. 
Występujące we wzorach (21) i (22) $\Delta \sigma_{E, 2}$ i $\Delta \tau_{E, 2}$ to równoważne zakresy zmienności naprężeń o stałej amplitudzie, odniesione do 2 milionów cykli. Obliczeniowe wartości zmienności naprężeń nominalnych $\gamma_{F f} \times \Delta \sigma_{E, 2}$ oraz $\gamma_{F f} \times \Delta t_{E, 2}$ wyznacza się następująco:

$$
\begin{gathered}
\gamma_{F f} \times \Delta \sigma_{E, 2}=\lambda_{1} \times \lambda_{2} \times \lambda_{\mathrm{i}} \times \ldots \times \lambda_{\mathrm{n}} \times \Delta \sigma\left(\gamma_{F f} \times Q_{k}\right) \\
\gamma_{F f} \times \Delta \tau_{E, 2}=\lambda_{1} \times \lambda_{2} \times \lambda_{\mathrm{i}} \times \ldots \times \lambda_{\mathrm{n}} \times \Delta \tau\left(\gamma_{F f} \times Q_{k}\right)
\end{gathered}
$$

gdzie: $\Delta \sigma\left(\tau \gamma_{F f} \times Q_{k}\right), \Delta \tau\left(\gamma_{F f} \times Q_{k}\right)$ - zakres zmienności naprężeń od obciążeń wywołujących zmęczenie, $\lambda_{i}$ - zastępcze czynniki uszkodzeń, zależne od widma obciążeń określonych normami, dotyczących różnych typów konstrukcji (mosty, kominy, wieże itp.).

Dla prostych konstrukcji, na które działa jednorodne widmo obciążenia, iloczyn $\lambda_{1} \times \lambda_{2} \times \lambda_{i} \times \ldots \times \lambda_{n}$ może być zastąpiony współczynnikiem równoważności $\lambda_{1}$, który pozwala przenieść zakres naprężenia o określonej liczbie cykli zmienności $\mathrm{N}$ na równoważny zakres naprężeń $\Delta \sigma_{E, 2}$, o liczbie cykli zmienności $2 \times 10^{6}$.

$$
\lambda_{\mathrm{I}}=\left(\frac{N}{2 \times 10^{6}}\right)^{\frac{1}{m}}
$$

Jeśli widmo naprężeń nie jest jednorodne i jedna z metod zliczania cykli charakteryzuje go w postaci zbioru kilku widm jednorodnych $\left(n_{E i}\right.$ i $\left.\Delta \sigma_{i}\right)$, to ocena zmęczenia polega na wyznaczeniu sumarycznego wskaźnika uszkodzenia $D_{d}$ na podstawie reguły
Palmgrena-Minera sumowania uszkodzeń zmęczeniowych $[19 \div 20]$ :

$$
D_{d}=\sum_{i}^{n} \frac{n_{E i}}{N_{R i}}
$$

gdzie: $n_{E i}$ - liczba cykli związana z zakresem zmienności naprężeń $V_{F f} \times \Delta \sigma_{i}$, w i-tym paśmie widma obliczeniowego; $N_{R i}$ - trwałość (liczba cykli) uzyskana na podstawie krzywej obliczeniowej $\left(\Delta \sigma_{c} / \gamma_{M f}\right)-\mathrm{N}_{\mathrm{R}}$, dla zakresu zmienności $\gamma_{F f} \times \Delta \sigma_{i}$ (rys. 10. wg [14]).

Warunkiem sprawdzania nośności zmęczeniowej jest spełnienie warunków:

- gdy rozpatruje się sumaryczne uszkodzenie:

$$
D_{d} \leq 1,0
$$

- gdy rozpatruje się równoważny zakres zmienności naprężeń:

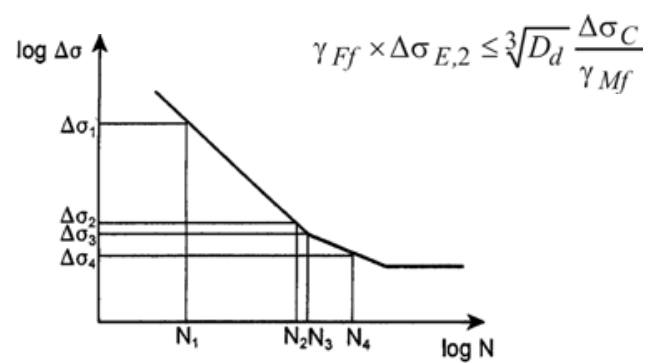

Rys. 10. Liczba cykli do zniszczenia wg [14]

Fig. 10. Number of fatigue cycles acc. to [14]

\section{Podsumowanie}

W euronormach przyjęto, uwzględniając programy komputerowe w analizie konstrukcji, że osią podłużną pręta jest oś $x-x$, a osiami przekroju poprzecznego są osie $y-y$ (pozioma) oraz $z-z$ (pionowa). Jednocześnie, dla stali konstrukcyjnej przyjęto oznaczać: granicę plastyczności symbolem $f_{y}$ i wytrzymałości na rozciąganie symbolem $f_{u}$, pozostawiając $\mathrm{w}$ normach hutniczych oznaczenia: $R_{\text {eh }}=f_{\mathrm{y}}$ i $R_{m}=f_{u}$.

Obliczanie połączeń spawanych wg normy PNEN 1993-1-8 [7] nie różni się znacząco od obliczeń według normy dotychczasowej PN-90/B-03200 [2]. Zasady obliczania, wprowadzone przez Eurokod 3, są bardziej ogólne, zbudowane na odmiennej filozofii i metodologii niż dotychczasowe normy polskie. Zawierają wiele odniesień do innych części Euroko-

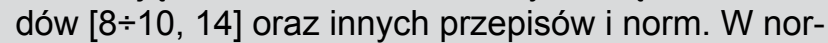
mie [7], w odróżnienu od normy [2], zamieszczono jedynie w szczątkowym stopniu zalecenia konstrukcyjne oraz ograniczenia technologiczne związane z wykonawstwem połączeń spawanych. Najważniejsze zmiany, wprowadzone przez normę [7], polegają na określeniu obliczeniowej wytrzymałości spoin pachwinowych, opartej na wytrzymałości materiału rodzimego (stali) na rozciąganie $f_{u}$, zamiast granicy plastyczności $f_{y}$, jak w normie [2]. Różnice polegają także na uściśleniu sposobu wymiarowania połączeń pachwinowych długich.
Zasady sprawdzania, ze względu na zmęczenie, elementów i połączeń spawanych podlegających znacznej liczbie zmian naprężeń, podane są w PN-EN 1993-1-9 [14]. Możliwe jest zastosowanie dwóch metod: metody naprężeń nominalnych lub metody naprężeń geometrycznych. Metoda naprężeń geometrycznych jest bardziej nowoczesna i dokładnie opisuje trwałość elementów i połączeń, wymaga jednak wyznaczenia naprężeń geometrycznych, których sposób wyznaczania nie został opisany w normie [14]. Metoda naprężeń nominalnych pozwala sprawdzić nośność na zmęczenie elementów spawanych i niespawanych, których materiał dobrano zgodnie z PN-EN 1993-1-10 [15]. Przyjmuje się, że zmęczenie powinno być sprawdzane, jeśli w czasie użytkowania konstrukcji liczba cykli zmian naprężeń jest większa niż $N=10^{4}$.

Obecnie przykłady obliczania połączeń i węzłów spawanych konstrukcji stalowych, zgodnie z Eurokodem 3, zostały przedstawione w trzech wydawnictwach książkowych [11, 13, 21] i w artykule [12]. Rozszerzone omówienie nośności spoin podlegających zmęczeniu wraz z przykładami ich obliczeń będzie przedstawione w tomie 2 pozycji [11]. 


\section{Literatura}

[1] Senkara J.: Czy złącze musi być najsłabszym miejscem konstrukcji? Biuletyn Instytutu Spawalnictwa, nr 5/2003.

[2] PN-90/B-03200. Konstrukcje stalowe. Obliczenia statyczne i projektowanie.

[3] Augustyn J.: Połączenia spawane i zgrzewane. Arkady, Warszawa 1987.

[4] Wichtowski B.: Wytrzymałość zmęczeniowa spawanych złączy doczołowych w stalowych mostach kolejowych. PN PSz nr 527. Wydawnictwo Politechniki Szczecińskiej, Szczecin 2002.

[5] Wichtowski B.: Korozja złączy spawanych w kominach przemysłowych. Przegląd Spawalnictwa, nr 10/1995.

[6] Hobracher A.: Kierunki rozwoju technik spawalnictwa i łączenia w wykonawstwie wyrobów niezawodnych i ekonomicznych. Biuletyn Instytutu Spawalnictwa, nr 2/2004.

[7] PN-EN 1993-1-8:2006. Eurokod 3: Projektowanie konstrukcji stalowych. Część 1-8: Projektowanie węzłów.

[8] PN-EN 1993-1-1:2006. Eurokod 3: Projektowanie konstrukcji stalowych. Część 1-1: Reguły ogólne i reguły dla budynków.

[9] PN-EN 1993-1-3:2006 (U). Eurokod 3: Projektowanie konstrukcji stalowych. Część 1-3: Reguły ogólne - Reguły uzupełniające dla konstrukcji z kształtowników i blach profilowanych na zimno.

[10] PN-EN ISO 5817:2009. Spawanie - Złącza spawane ze stali, niklu, tytanu i ich stopów (z wyjątkiem spawanych wiązką) - Poziomy jakości według niezgodności spawalniczych.

[11] Bródka J., Kozłowski A. (red.): Projektowanie i obliczanie połączeń i węzłów konstrukcji stalowych, t. 1. PWT, Rzeszów 2009.
[12] Kozłowski A., Ślęczka L., Wierzbicki S.: Projektowanie połączeń spawanych wg PN-EN 1993-1-1 i PN-EN 1993-1-8. Inżynieria i Budownictwo, $\mathrm{nr}$ 3/2008.

[13] Bródka J., Bronowicz M.: Projektowanie konstrukcji stalowych zgodnie z Eurokodem 3-1-1 wraz z przykładami obliczeń. Wydawnictwo Politechniki Białostockiej, Białystok 2001.

[14] PN-EN 1993-1-9:2007: Eurokod 3. Projektowanie konstrukcji stalowych. Część 1-9: Zmęczenie.

[15] PN-EN 1993-1-10:2007: Eurokod 3. Projektowanie konstrukcji stalowych. Część 1-10: Udarność i ciągliwość międzywarstwowa.

[16] Wichtowski B.: Ocena zmęczenia i doboru stali na konstrukcje stalowych mostów spawanych wg Eurokodu 3. Przegląd Spawalnictwa, nr 12/2009.

[17] Wichtowski B.: Kategoria zmęczeniowa spoin czołowych poprzecznych badanych laboratoryjnie. Inżynieria i Budownictwo, $\mathrm{nr} 5 / 2007$.

[18] Goss Cz., Kłysz S., Wojnowski W.: Problemy niskocyklowej trwałości zmęczeniowej wybranych stali i połączeń spawanych. WITWL, Warszawa 2004.

[19] Gurney T.R.: Zmęczenie konstrukcji spawanych. WNT, Warszawa 1973.

[20] Kocańda S., Szala J.: Podstawy obliczeń zmęczeniowych. PWN, Warszawa 1997.

[21] Kozłowski A. (red.): Konstrukcje stalowe - Przykłady obliczeń według PN-EN 1993-1. Część pierwsza - Wybrane elementy i połączenia. OWPRz, Rzeszów 2009.

\section{Mikrospawarka StarWeld Tool Integral}

Na zeszłorocznych targach ExpoBlach ToolTech 2010, odbywających się w dniach $12 \div 15$ października 2010 r. w Krakowie, firma Soditronic na swoim stoisku zaprezentowała mikrospawarkę laserową StarWeld Tool Integral firmy Rofin. Urządzenie wyposażone jest w źródło Nd:YAG (1064 $\mathrm{nm}$ ) o mocy nominalnej $200 \mathrm{~W}$ i maksymalnej mocy w impulsie $12 \mathrm{~kW}$. Spawanie realizowane jest automatycznie wg zadanej trajektorii lub prowadzenie wiązki po powierzchni materiału realizowane jest ręcznie przez specjalnie przygotowane do tego celu otwory w obudowie urządzenia. Mocowanie elementów odbywa się na przesuwanym stole umożliwiajacym obróbkę części o długości do $500 \mathrm{~mm}$ i masie do $350 \mathrm{~kg}$, chociaż spawanie realizowane przy otwartej komorze powoduje, że gabaryty łączonych elementów mogą znacznie przekraczać pojemność komory. Optyka pozwala na dowolne prowadzenie wiązki lasera wzdłuż dwóch osi. Pionowe płaszczyzny, podcięcia, głębokie rowki i inne obszary o utrudnionym dostępie mogą być spawane bez obracania lub pochylania detalu, co jest szczególnie istotne przy spawaniu dużych i ciężkich form lub narzędzi.

Spawanie ręczne prowadzone jest przez okular mikroskopu zamontowanego w górnej części urządzenia o dziesięciokrotnym lub szesnastokrotnym powiększeniu. Całość procesu można obserwować na monitorze. Zarówno monitor, jak i mikroskop stanowią integralne wyposażenie urządzenia dostarczane przez producenta.

Kompaktowa konstrukcja urządzenia zawiera układ chłodzenia i generator wiązki oraz komorę roboczą wraz z ruchomym stołem roboczym. Wewnątrz urządzenia

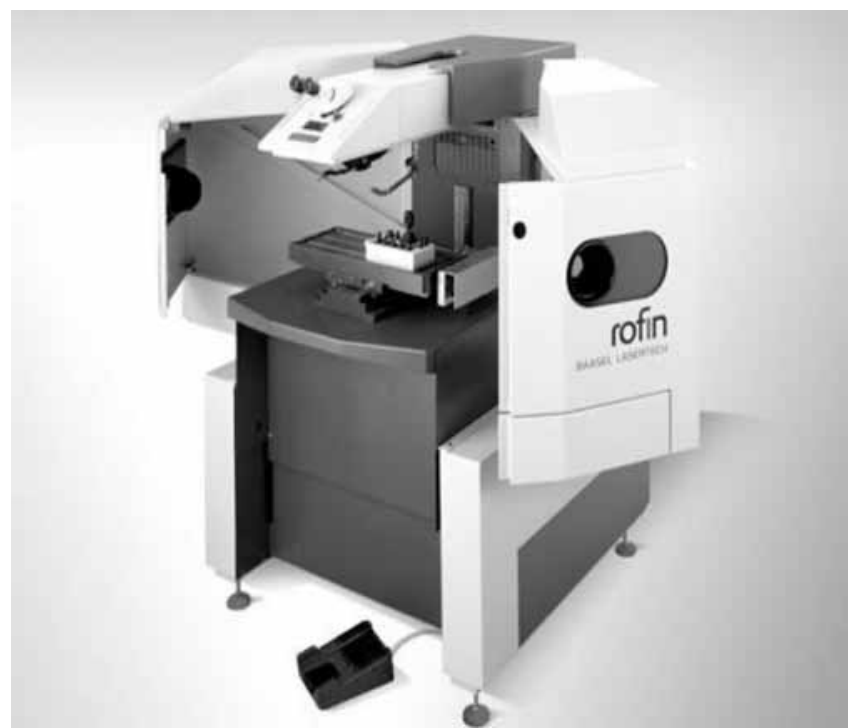

rozprowadzone zostały również przewody doprowadzające gazy ochronne doprowadzane $z$ butli. Przewody gazowe są podłączone za pomocą szykbkozłączek zamocowanych w obudowie urządzenia.

Podczas targów prezentowane było urządzenie pracujące - oglądający mogli samodzielnie wykonywać złącza materiałów dostępnych na stoisku Soditronic, jak również przyniesionych przez siebie.

Lechosław Tuz 